\title{
NAPPE STRUCTURE OF THE NORTH SPORAdES (GREECE): ON THE GEOLOGICAL EVOLUTION OF ALONNISOS ISLAND
}

\author{
Jacobshagen $\mathrm{V}^{1}$ and Matarangas $\mathrm{D} .^{2}$ \\ ${ }^{1}$ Institute of Geological Sciences, Free University of Berlin, D-12249 Berlin, Germany, \\ vojac@zedat.fu-berlin.de \\ ${ }^{2}$ Institute of Geology and Mineral Exploration (IGME), GR-11527 Athens, Greece, \\ dmatar@igme.gr
}

\begin{abstract}
On Alonnisos island detailed field studies were carried out concerning rock sequences and their boundaries, geochemical analyses of mafic volcanic rocks, and geological mapping of key areas in the southwestern and central parts of the island to the scale 1:10 000. In connection with already published data, our results led to a revision of the tectonic structure of the island and of its geological evolution. The deeper parts of Alonnisos are built up by Mesozoic rocks of the Pelagonian zone, locally with outliers of the Eohellenic nappe on top. Both units are covered by the well-known Mesoautochthonous sequence of Upper Cretaceous/Lower Tertiary age. These units are tectonically overlain by relics of the Palouki nappe, which consists of the probably Lower Cretaceous Palouki formation (once called "Palouki series"), followed by Upper Cretaceous marbles and by a metaflysch. This nappe was probably overthrust during the Eocebe (Mesohellenic) orogeny.
\end{abstract}

Relics of the Palouki nappe can be followed from Alonnisos to Skopelos in the SW, over some small islands. As the rock association in its older parts point to a pelagic marine origin, we assume that the Palouki nappe had its origin in a relic of the Vardar ocean. Relations to other nappe ouliers, which hold a comparable position in the Sporades/Pelion region, are discussed.

\section{INTRODUCTION}

In the past decades, the North Sporades islands (see Fig. 1) have more and more attracted the interest of regional geology. After a first overview on the major islands by Guernet (1971), special studies have been published on Skiathos (Ferentinos 1972) and Alonnisos (Kelepertsis 1973, 1974, 1975). Later on, Jacobshagen and Wallbrecher (1984) have deduced a generalizing structural scheme for the whole region, based on large-scale geological mapping and detailed stratigraphical and structural analyses on the islands of Skyros (Harder et al. 1983) and Skiathos (Heinitz and Heinitz-Richter 1983) and on the Magnesian peninsula (Wallbrecher 1976). These authors found the following three tectono-stratigraphic stockworks everywhere, from top to bottom

\section{Mesoautochthonous complex \\ Eohellenic nappe relics \\ Pelagonian units}

The same structural sequence was found on Skopelos island by Matarangas (1992). But on some Sporades islands, relics of Eocene (Mesohellenic) nappes were recognized even on top of the Mesoautochthonous complex. On one hand, the small island of Paleo Trikkeri (off the western end of the Magnesian peninsula, Fig. 1) is crowned by an ophiolite oulier, which rests upon Mesoautochthonous flysch (Jacobshagen et al. 1977). On the other hand, an outlier of marbles and mica-schists (Skyros unit, Harder et al., 1983) is overthrust upon the Mesoautochthonous of Skyros island. 


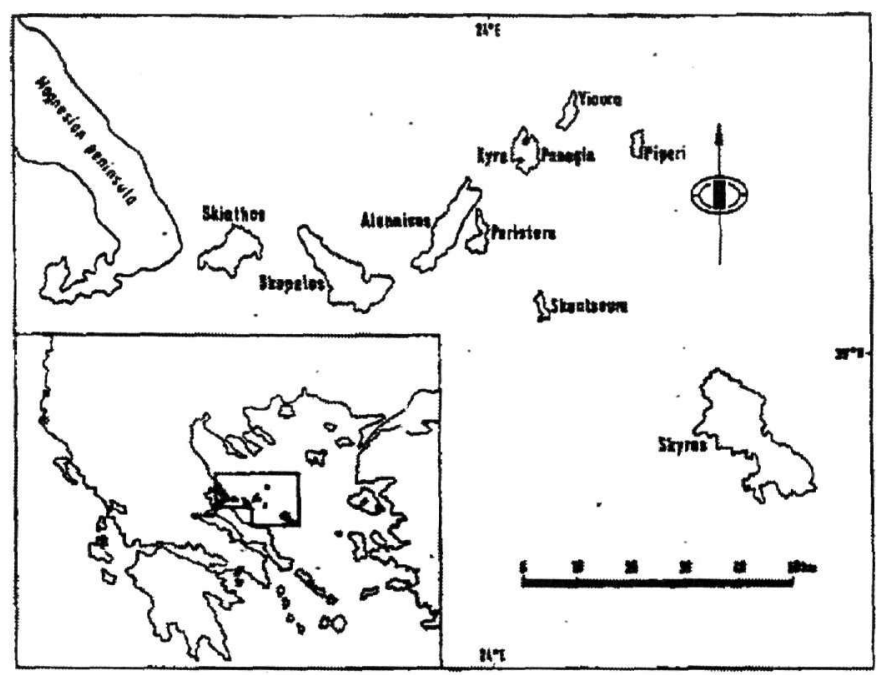

Figure 1. Location of the North Sporades. P.T. Paleo Trikkeri

On the base of these results the present authors have started a stratigraphical and structural reinvestigation of Alonnisos island. This research includes also geological mapping to the scale 1:10 000 of the southwestern part (Kriwet 1995) and of a key area in the eastern central region of the island (Frank 1997), and geochemical investigations of Eohellenic metabasites from the central part (Pe-Piper et al. 1996). In a preliminary note the structural sequence listed above could be confirmed for Alonnisos island (Jacobshagen and Matarangas 1993). There, the Mesoautochthonous complex is, however, overthrust by rocks of the Cretaceous Palouki formation (formerly called "Palouki series") which forms the base of a separate nappe, called the Palouki nappe (see below) in the same way as observed on Skopelos by Matarangas (1992). These alpine structures of the island are covered by Neogene deposits. which are exposed mainly in an area near the southwestern end of the island and, moreover, in small patches within its central and northern parts (Fig.2). The Neogene sediments are not considered in this study.

\section{THE PRE-NEOGENE UNITS}

The pre-Neogene units of Alonnisos may be briefly characterized below by their rock associations and stratigraphic data. A tectono-stratigraphical column for all pre-Neogene units is presented in Fig. 3.

\subsection{Pelagonian unit}

This deepest tectonic unit of the North Sporades is widely exposed in the northern and central parts of Alonnisos (Fig.2) and is totally composed of meta-carbonates. The lower parts of these marbles are dolomitic and of !ight grayish color, thin- to medium-bedded, but including some thick layers $(0.5-1 \mathrm{~m})$ as well. Although we did not find any fossils within the dolomite marbles, we assume a Triasso-Jurassic age for this member, as documented in an identic sequence of of Skope

los by Matarangas and Skourtsis-Coroneou (1989). The upper parts of the Pelagonian marbles are throughout calcitic. Near the base these are dark to medium gray and thick-bedded ("Kalamaki beds" of Kelepertsis 1974). This author also mentioned some fossils of Kimmeridgean age (Cladocoropsis sp. and Codiaceae). Higher up the calcitic marbles become light gray and nearly unbedded (called "Steni Vala beds" by Kelepertsis). These have delivered some Tithonian fossils (Kelepertsis 1974). The outcrupping thickness of the Pelagonian marbles is about $500 \mathrm{~m}$ on Alonnisos island. 


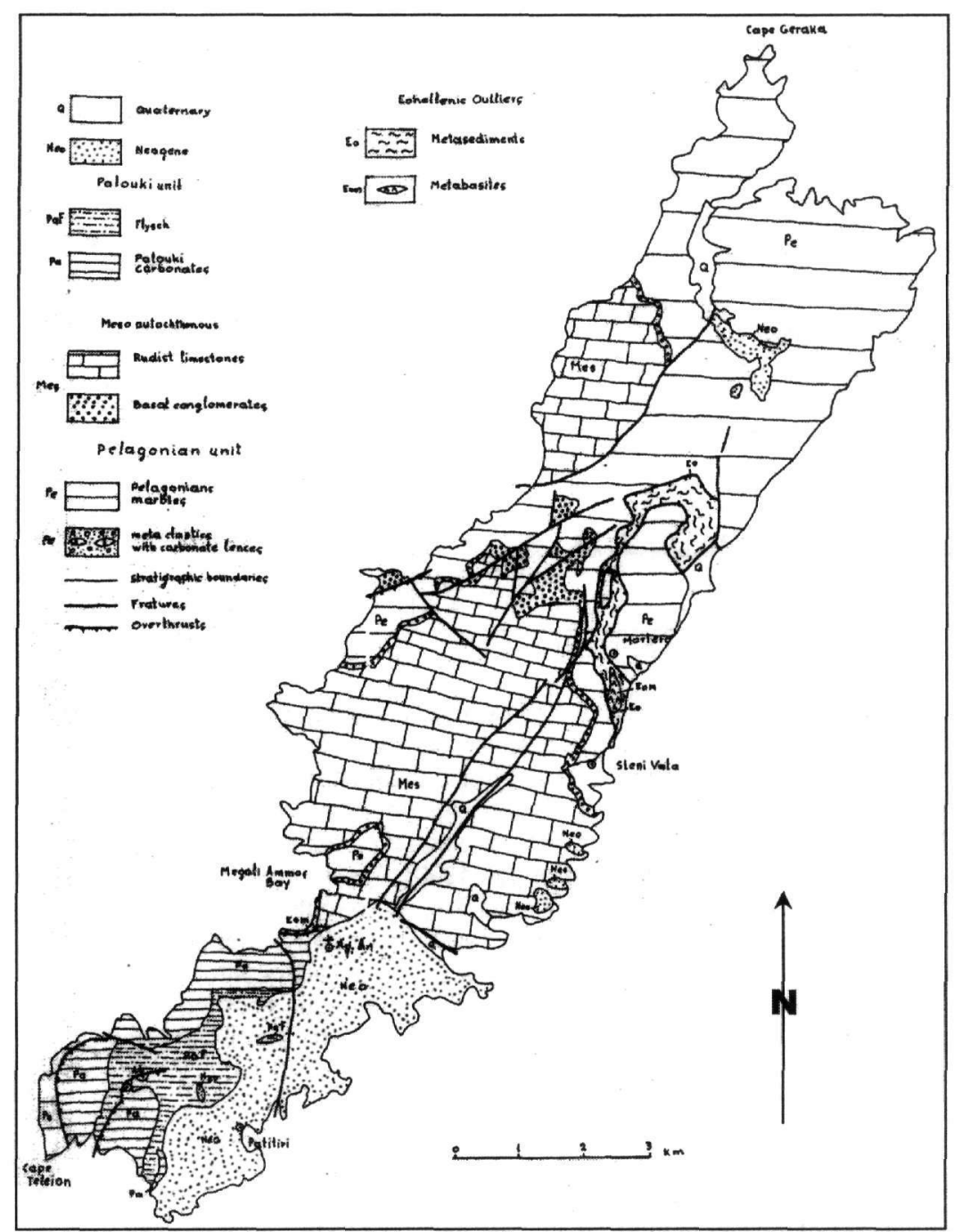

Fig. 2. Geological sketch- map of Alonnisos island, based on Kelepertsis (1975). The southwestern part of the island was drawn after Kriwet (1995), the eastern central part (areas around Steni Vala und Mortero) after Frank (1997)

\subsection{Eohellenic relics}

On Alonnisos, there exists only one well documented outlier of the Eohellenic nappe, which is situated north of Steni Vala cind Mortero in the central part of the island (Fig. 2). For the assemblage of its rocks. Kelepertsis $(1973,1974)$ had created the term "Mortero series". This area was recently mapped in detail by Frank (1997). It shows mainly grayish phyllites and calcschists, with intercalations of thin-bedded black marbles and quartzites. The latter are obviously metaturbidites, as they exhibit a distinct graded bedding from microconglomeratic to fine-grained psammitic layers in places. The metasediments show a low-grade metamorphism, but did not deliver high pressure indications, up to now. All rocks are strongly deformed, showing disrupted isoclinal folds and boudinage. As a whole, they are overthrust on the Pelagonian marbles below. South of Mortero the metasediments include a big lense of metabasitic rocks. According to geochemical analyses of $\mathrm{Pe}-$ Piper et al. (1996), most of these metabasites were identified as members of an arc-tholeiite series, ranging from basalt to rhyodacite with very low LILE concentrations and very low $\mathrm{Nb}, \mathrm{Ta}, \mathrm{Y}$ and $\mathrm{Ti}$. 
These indications point to an oceanic origin. On account of their geochemical character, they can not be related with the unde-lying Pelagonian unit, but are analogues of Eohellenic ophiolites of eastern Greece.

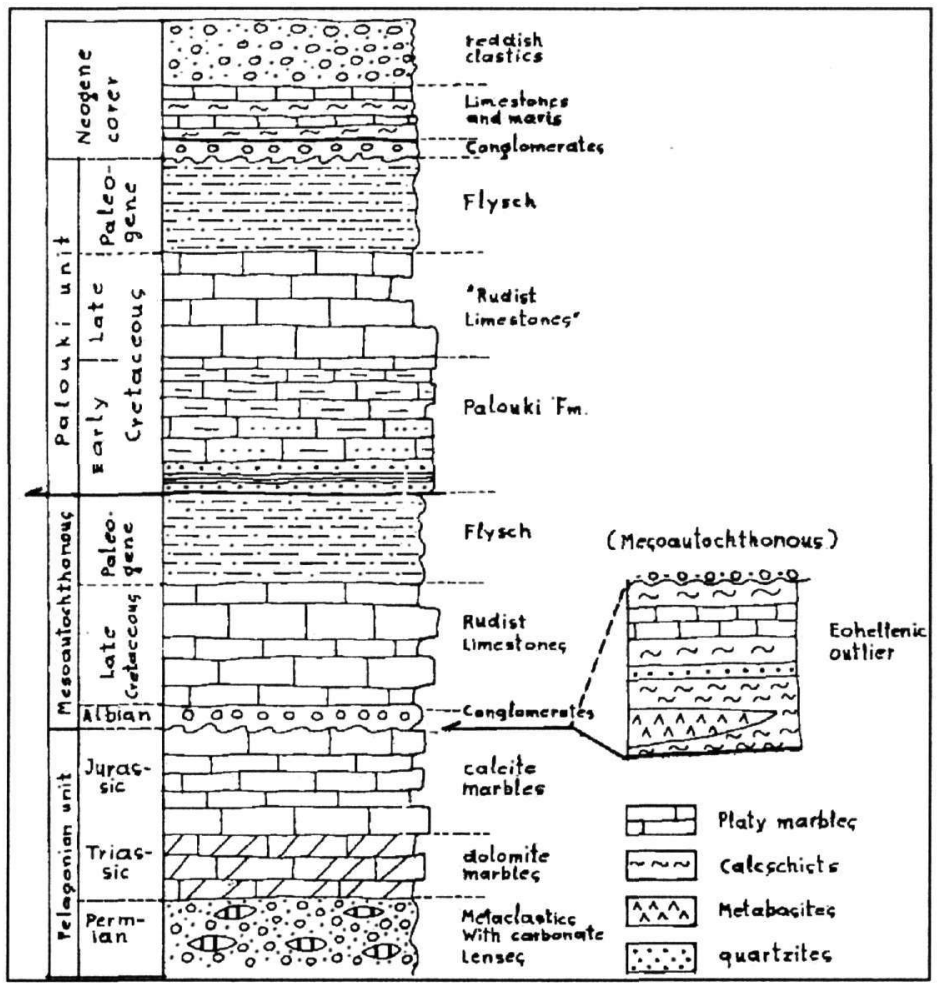

Fig. 3. Tecton-stratigraphic column of Alonnisos island

The association of the metasediments with metabasalts described, the geochemical character of the latter, and the style of tectonic deformation point clearly to an oceanic subduction complex. It fits, moreover, well to the compositions of the Eohellenic outliers of Skyros and Skopelos islands (Harder et al. 1983, Matarangas 1992) and of the Magnesian peninsula (Wallbrecher 1996).

Moreover, an isolated body of metabasites crops out along the sea shore of Megali Ammos Bay, west of the chapel of Ag. Anargyri. On its top, it is overthrust by rocks of the Palouki unit, whereas its base is hidden by the sea. Thus, it remains an open question, whether these metabasites have in fact been part of the Eohellenic nappe or have to be considered as a tectonic sliver at the base of the Palouki unit (see below).

In all other parts of the islend, the Mesoautochthonous complex rests directly on the Pelagonian unit. We suppose, however, that the Eohellenic nappe once had covered the whole Pelagonian unit, but was eroded later, in early Cretaceous times.

\section{Mesoautochthonous complex}

The Mesoautochthonous complex (Jacobshagen 1986) covers large areas in the central part of Alonnisos (Fig. 2). Here, it consists only of two stratigraphical units: the Basal Conglomerates and the overlying Rudist Limestores. Mesoautochthonous flysch, which is known from other islands of the North Sporades, is nowhere preserved. The following descriptions of the Mesoautochthonous complex refer widely to Kelepertsis (1974) and Kriwet (1995).

The Basal Conglomerates rest upon a karstic relief, which contains relics of metabauxite filling in places. Related to the form of their clasts, they change from real conglomerates to breccias, with 
a matrix of variegated sandst. one. The components of the psephitic beds show a broad lithological spectrum, with variegated sandstones and Eohellenic metasediments and metabasalts prevailing over Pelagonian marbles and quartz pebbles. This variety documents a short period of erosion in Early Cretaceous times and may explain, why the Eohellenic nappe was reduced to only small relics on Alonnisos island. The thickness of the Basal Conglomerates reaches up to $8 \mathrm{~m}$. According to Kelepertsis (1973), they were deposited in Albian or Cenomanian times. On the neighboring island of Skopelos, a small fauna of foraminifera testifies to an Albian age (Matarangas 1992).

With a thickness of several hundred meters, the Rudist Limestones consist mainly of thickbedded to massive, roughly r.3crystallised grayish marbles, which locally include some thin-bedded and even sandy layers. Furtharmore, conglomeratic and brecciated carbonate beds are included in places. Relics of rudists were observed on two localities by Kelepertsis (1974). The age of the Rudist Limestones is assumed to be Cenomanian-Turonian, but no fossils were found on Alonnisos, which would allow a definite age determination.

\subsection{Palouki nappe}

The Palouki nappe is confined to the southwestern part of Alonnisos island (Fig. 2), where it overlies Pelagonian marbles .r Eohellenic metabasites, respectively, with tectonical contacts. The rocks of the Palouki unit are crinted by a weak metamorphism. Three stratigraphic formations could be discerned: the Early Cretaceous Palouki formation at the base, overlain by Late Cretaceous "Rudist marbles", and, finally, by the Palouki flysch (Fig. 3). The following descriptions include some observations of Kriwet (1995), as well.

Palouki formation: With this new stratigraphical name we replace the term "Palouki series" of former authors (e.g. Guernet 1971, Kelepertsis 1974, Jacobshagen and Skala 1977) according to the rules of international stratigraphical nomenclature. The Palouki formation consists of an alternation of marbles, metasandsto nes, and schists. The marbles are mostly light gray and thin-bedded. Frequently, they contain lenses or layers of metacherts. The metasandstones show singular major grains of quartz or feldspar in a fine-grained quartzitic matrix, which contains also some sericite and chlorite. In higher parts of the Palouki formation the metasandstones are more and more replaced by thin phyllite layers. In places, the Palouki formation contains, moreover, lenses of dark gray metapelites. Fossils could not be found in the Palouki formation of Alonnisos. But referring to microfossils found in that formation on Skopelos by Matarangas (1992), it might be of Lower Cretaceous age as well.

On its top, the Palouki formation passes into the "Rudist Limestones". This transition can be observed in the nearest vicinity of Alonnisos village and at the OTE tower NE of the village. The "Rudist Limestones" are composed of thick-bedded to massive marbles of white to gray colors, which do not contain nodules and layers of metacherts. We consider these marbles as a stratigraphic and facies equivalent to the Rudist Limestones of the Mesoautochthonous complex, although they did not deliver rudists on Alonnisos island up to now (on that reason, we write their name in quotation marks). The age of the "Rudist Limestones" of the Palouki unit is probably Cenomanian-Turonian, according to some foraminifera found by Kelepertsis (1974) in a corresponding rock unit of Alonnisos.

The Palouki flysch consists of an alternation of usually thin-bedded metapelites, metasandstones, quartzites, and some recrystallised limestones. From the "Rudist marbles" below, this flysch formation develops continuously within a few meters of an alternation, which can to be observed near the OTE tower and at Cape Telion, the southwestern end of the island. The thickness of the Palouki flysch exceeds at least a few hundred meters. The rocks of the Palouki flysch are intensely deformed by small-scale folding, which shows a cross-folding pattern with axes striking to the N.NW and to the NE, respectively (Jacobshagen and Skala 1977).

Contrary to our view, Kelepertsis $(1974,1975)$ believed the Palouki formation to be a special facies of the Upper Cretaceous Rudist Limestones of the Mesoautochthonous complex and, consequently, included the higher members of the Palouki unit in the Mesoautochthonous as well. But this opinion became invalid, since the age of the Palouki formation was dated to Lower Cretaceous on Skopelos island. 


\section{ORIGIN OF THE PALOUKI NAPPE: DISCUSSION AND CONCLUSIONS}

Character and origin of the Palouki nappe can not be derived from observations on Alonnisos only. It is necessary to refer to the situation in the Mt. Palouki area of southeastern Skopelos, as well. There, the Palouki unit shows the same sequence of metasedimentary formations as on Alonnisos, but is clearly overthrust on flysch of the Mesoautochthonous complex (Matarangas 1992, 1995). This tectonic contact is, moreover, marked by slivers of metabasalts, serpentinites, and schists, which consequently were included in the Palouki unit. Therefore it seems possible to attribute the metabasalts of Megali Ammos Bay on Alonnisos island (see above) not to the Eohellenic nappe, but to the base of the Palouki unit, alternatively.

Thus, the Palouki outliers of Skopelos and Alonnisos islands are considered to be parts of a separate nappe. On account of its position on top of Mesoautochthonous flysch this nappe must have been overthrust in Tertiary times, probably during the Eocene (Mesohellenic) orogeny, because on Alonnisos the Palouki unit is covered by post-orogenic sediments of the Miocene.

Which was the origin of the rocks of the Palouki nappe? Both the serpentinite and metabasalt slivers at its base and the metasediments of the Lower Cretaceous Palouki formation point to a deep marine environment of oceanic character, which might have been a relic of the former Vardar ocean. Later, it was uplifted to neritic depths in Upper Cretaceous times ("Rudist marbles"). Finally, in the early Tertiary, the area might have been situated on a slope in front of a developing orogenic range (Palouki flysch).

Another question concerns the geodynamic conditions of metamorphism of the Palouki rocks. Up to now, systematic petrographical investigations were not carried out in the Palouki unit. The published geological studies documented only a few phyllosilicate minerals, which indicate temperatures of a low-grade or even very low-grade overprint, but no indications were found to define the contemporaneous pressures. Anyway, large-scale recumbent folds on Skopelos (Matarangas 1992) as well as Fe-carpholite from Mesoautochthonous flysch of Skopelos (Mposkos and Liati 1990) give hints to processes at elevated pressures during the Eocene.

Summarizing, we state that in the region of the Magnesian peninsula and the North Sporades islands relics Eocene (Mesohellenic) nappes were found on four places, up to now. At three of them (Paleo Trikkeri, Skopelos, and Alonnisos islands), these outliers are of an oceanic origin, whereas on the fourth one (Skyros island) it is composed of metamorphic rocks of a continental basement. But it is too early to deduce a geotectonic model from these results, which were achieved on a few islands with big distances in between.

\section{REFERENCES}

Ferentinos, G.C., 1972. The geology-petrology of the island of Skiathos. Ph.D. thesis Univ. Patras. (in Greek, with English summary).

Frank, R., 1997. Geologische Geländearbeit an der Ostküste von Alonnisos, Nord-Sporaden/Griechenland. Diplomkartierung Freie Universität Berlin, $46 \mathrm{pp}$. (unpublished).

Guernet, C., 1971. Etudes géologiques en Eubée et dans les régions voisines (Grèce). Thèse d'Etat Univ. Paris, 395 pp., Paris.

Harder, H., Jacobshagen, V., Skala, W., Arafeh, M., Berndsen, J., Hofmann, A., Kusserow, H., and Schedler, W., 1983. Geologische Entwicklung und Struktur der Insel Skyros, Nordsporaden, Griechenland. Berliner geowissenschaftliche Abhandlungen, (A), 48, pp. 7-40. Berlin.

Heinitz, W., and Richter-Heinitz, I., 1983. Geologische Unteersuchungen im Nordost-Teil der Insel Skiathos (Griechenland). Berliner geowissenschaftliche Abhandlungen, (A), 48, pp. 41-63. Berlin.

Jacobshagen, V. (ed.), 1986. Geologie von Griechenland. 363 pp., Berlin-Stuttgart, Borntraeger.

Jacobshagen, V., and Matarangas. D., 1993. Nappe structure of Alonnisos island, North Sporades. A preliminary note. Festschrift A. G. Panagos, vol.1, pp. 365-372. Athens (Techn. Univ.).

Jacobshagen, V., and Skala, W., i977. Geologie der Nord-Sporaden und die Strukturprägung auf der mittelägäischen Inselbrücke. Ann. géol. Pays hellén., 28, pp. 233-274. Athens.

Jacobshagen, V., and Wallbrecher, E., 1984. Pre-Neogene nappe structure and metamorphism of the North Sporades and the southern Pelion peninsula.

In: J.E.Dixon and A.H.F. Robertson (eds.), The geological evolution of the Eastern Mediterranean. Geological Society, Special Publ., 17, 591-602. Oxford, Blackwell. 
Jacobshagen, V., Märtz, J., and Reinhardt, R., 1977. Eine alttertiäre Ophiolith-Decke in den inneren Helleniden NE-Griechenlands. Neues Jahrb. Geol. Paläont., Monatshefte, 1977, 613-620. Stuttgart.

Kelepertsis, A.E., 1973. The geology of Alonnisos and Peristera. Ph.D. thesis Univ. Patras, 115 pp. (in Greek with English summary).

Kelepertsis, A., 1974. Geological structure of Alonnisos and Peristera islands. Zeitschrift der Deutschen Geologischen Gesellschaft, 125, 225-236. Hannover.

Kelepertsis, A., 1975. Geological map of Greece 1:50000. Alonnisos and Skantzoura islands. Athens. National Institute of Geology and Mining Exploration (IGME).

Kriwet, J., 1995. Geologie des südlichen Bereiches der Insel Alonnisos (Nord-Sporaden, Griechenland). Diplomkartierung Freie Universität Berlin, 57 pp. (unpublished)

Matarangas, D., 1992. Geological investigations of Skopelos island (North Sporades, Greece). Berichte des Forschungszentrums Jülich, 2684, 157 pp. Jülich.

Matarangas, D., 1995. Geological map of Greece 1:50000. Skopelos island. Athens, Institute of Geology and Mining Exploration (IGME).

Matarangas, D., and Skourtsis-Coroneou, V., 1989. Stratigraphical data from a metamorphic sequence of the North Sporades (Pelagonian zone, Greece). Neues Jahrb. Geol. Paläont., Monatshefte, 1989, pp. 182-192.

Pe-Piper, G., Matarangas, D., and Jacobshagen, V., 1996. The Mesozoic metavolcanic rocks of Alonnisos and Kyra Panagia islands, Sporac'es, Greece. Neues Jahrbuch für Mineralogie, Monatshefte, 1996, pp. 251-263. Stuttgart.

Wallbrecher, E., 1976. Geologie und Tektonik auf dem Südteil der Magnesischen Halbinsel (Nordgriechenland). Zeitschrift der Deutschen Geologischen Gesellschaft, vol. 127, pp. 365-371. Hannover. 